\title{
Biohythane production from marine macroalgae Sargassum sp. coupling dark fermentation and anaerobic digestion
}

\author{
José C. Costa, João V. Oliveira, Maria A. Pereira, Maria M. Alves, Angela A. Abreu* \\ CEB - Centre of Biological Engineering, University of Minho, 4710-057 Braga, Portugal
}

\section{H I G H L I G H T S}

- Biohythane production from Sargassum sp. is feasible and has a high potential.

- Hydrogen yield of $91.3 \pm 3.3 \mathrm{~L} \mathrm{H}_{2}$ per $\mathrm{kg}$ (VS) of Sargassum sp. was attained.

- It was achieved a methane yield of $541 \pm 10 \mathrm{~L} \mathrm{CH}_{4}$ per $\mathrm{kg}$ (VS) of Sargassum sp.

- Potential energy production from Sargassum sp. was estimated in $242 \mathrm{GJ} \mathrm{ha}^{-1} \mathrm{yr}^{-1}$.

- The value of estimated energy could result in $600 \mathrm{EJ} \mathrm{yr}^{-1}$.

\section{A R T I C L E I N F O}

\section{Article history:}

Received 24 February 2015

Received in revised form 13 April 2015

Accepted 16 April 2015

Available online 29 April 2015

\section{Keywords:}

Biohythane

Marine biomass

Sargassum sp.

Biohydrogen

Caldicellulosiruptor saccharolyticus

\begin{abstract}
A B S T R A C T
Potential biohythane production from Sargassum sp. was evaluated in a two stage process. In the first stage, hydrogen dark fermentation was performed by Caldicellulosiruptor saccharolyticus. Sargassum sp. concentrations (VS) of 2.5, 4.9 and $7.4 \mathrm{~g} \mathrm{~L}^{-1}$ and initial inoculum concentrations (CDW) of 0.04 and $0.09 \mathrm{~g} \mathrm{~L}^{-1}$ of $C$. saccharolyticus were used in substrate/inoculum ratios ranging from 28 to 123 . The end products from hydrogen production process were subsequently used for biogas production.

The highest hydrogen and methane production yields, $91.3 \pm 3.3 \mathrm{~L} \mathrm{~kg}^{-1}$ and $541 \pm 10 \mathrm{~L} \mathrm{~kg}^{-1}$, respectively, were achieved with $2.5 \mathrm{~g} \mathrm{~L}^{-1}$ of Sargassum sp. (VS) and $0.09 \mathrm{~g} \mathrm{~L}^{-1}$ of inoculum (CDW). The biogas produced contained $14-20 \%$ of hydrogen. Potential energy production from Sargassum sp. in two stage process was estimated in $242 \mathrm{GJ} \mathrm{ha}^{-1} \mathrm{yr}^{-1}$. A maximum energy supply of $600 \mathrm{EJ} \mathrm{yr}^{-1}$ could be obtained from the ocean potential area for macroalgae production.
\end{abstract}

(c) 2015 Elsevier Ltd. All rights reserved.

\section{Introduction}

Hythane, a mixture of hydrogen and methane, usually with 10-25\% hydrogen in volume, is an important future fuel (Ljunggren and Zacchi, 2010). By adding hydrogen to methane, the $\mathrm{H} / \mathrm{C}$ ratio is increased, reducing the greenhouse gas emissions. In addition, the fuel efficiency is improved since the narrow range of flammability of methane is extended, the flame speed of methane can be greatly increased, eventually reducing combustion duration and improving heat efficiency, and the quenching distance of methane can be reduced, making the engine easy to ignite with less input energy (Liu et al., 2013). This hydrogen rich source of biofuel can promote an incremental introduction of hydrogen to the fueling infrastructure and accelerate transition of the market towards a hydrogen economy (Bauer and Forest, 2001; Das et al., 2000).

\footnotetext{
* Corresponding author.

E-mail address: angela_abreu@deb.uminho.pt (A.A. Abreu).
}

Hydrogen and methane can be biologically produced through a two-stage process coupling dark fermentation and anaerobic digestion (Banks et al., 2010; Lu et al., 2009; Ljunggren and Zacchi, 2010). Hydrogen dark fermentation at hyperthermophilic and extremely thermophilic conditions has been associated to higher productivities (Abreu et al., 2010, 2012). In addition to the high polysaccharide-hydrolysing capacities of many extreme and hyperthermophilic microorganisms, an important advantage is their ability to use most of the reducing equivalents (e.g. NADH, reduced ferredoxin) formed during glycolysis for the production of hydrogen (Verhaart et al., 2010). Extreme thermophilic bacteria, such as Caldicellulosiruptor saccharolyticus are reported to approach the theoretical maximum yield of $4 \mathrm{~mol} \mathrm{H}_{2} \mathrm{~mol}^{-1}$ glucose (van Niel et al., 2002; Willquist et al., 2010). The hydrolysates resulting from dark fermentation, rich in volatile fatty acids (VFA), can be converted to methane through an anaerobic digestion process (Costa et al., 2012). Alternatively a photofermentation process can follow the dark fermentation step, but this alternative has shown limited cost efficiency especially concerning the nutrients requirements 
and the costs of photobioreactors (final report of the Hyvolution EU project - http://www.biohydrogen.nl/hyvolution/32288/9/0/20). In the sequence of the EU project Hyvolution, the project Hytime considers a two step dark fermentation-anaerobic digestion process (http://www.hy-time.eu/hytime/32562/5/0/30).

Several studies have been done on biohythane production from pure sugars and from feedstocks, such as by-products from the agricultural and food industry, municipal waste, or wastewaters (Liu et al., 2013). However, there are no studies describing the production of biohythane in a two-step fermentation process from a marine macroalgae biomass.

Macroalgae cultivation does not involve the use of feed, fertilizer, pesticides or other chemicals. Macroalgae growth is fueled only by natural nutrients in seawater as well as solar energy and carbon dioxide. Moreover, macroalgae contain easily hydrolysable sugars and proteins, low fractions of lignin and high fractions of hemicellulose and a good hydrolysis yield making this biomass suitable for anaerobic fermentation (Briand and Morand, 1997; Nkemka and Murto, 2010). The energy potential of marine biomass is estimated to be more than $100 \mathrm{EJ} \mathrm{yr}^{-1}$, significantly higher than the terrestrial biomass $\left(22 \mathrm{EJ} \mathrm{yr}^{-1}\right.$ ) or municipal solid waste $\left(7 \mathrm{EJ} \mathrm{yr}^{-1}\right.$ ) (Chynoweth et al., 2001). Sargassum sp. is a genus of brown free floating macroalgae that has a global occurrence.

The main objective of this study is to evaluate the potential of Sargassum sp. biomass for the generation of hydrogen enriched biogas (10-25\% of $\mathrm{H} 2$ ) and determine the associated potential energy generation. For this, the extreme thermophilic bacterium C. saccharolyticus was used for hydrogen production on the first step of the process, followed by biogas production from anaerobic digestion of the resulting fermentation products. C. saccharolyticus is used in the present study due to its excellent polysaccharide-hydrolyzing capacity and because it is able to use most of the reducing equivalents formed during glycolysis for the production of hydrogen. $C$. saccharolyticus is referred as relatively insensitive to high $\mathrm{pH}_{2}$. Moreover, this organism has recently gained increased interest due to its ability to produce thermostable cellulolytic and xylanolytic enzymes, to grow on complex lignocellulosic carbon sources, and to co-metabolize a wide spectrum of monosaccharides including both pentose and hexose sugars.

\section{Methods}

\subsection{Biomass characterization}

Sargassum sp. was collected in the spring of 2013 from a location in the north coastline of Portugal (Póvoa de Varzim). The macroalgae was dried at room temperature and then milled into pieces with less than $0.5 \mathrm{~cm}$. Sargassum sp. biomass was characterized in terms of total and soluble Chemical Oxygen Demand (COD), total solids (TS), volatile solids (VS), Total Kjeldahl Nitrogen (TKN), fat content, Klason lignin, glucan and xylan content.

\subsection{Hydrogen production assays}

\subsubsection{Culture and medium}

C. saccharolyticus DSM 8903 was obtained from the Deutsche Sammlung von Mikroorganismen und Zellkulturen (DSMZ). The culture medium consisted of (per L): $\mathrm{KH}_{2} \mathrm{PO}_{4} 0.75 \mathrm{~g}, \mathrm{~K}_{2} \mathrm{HPO}_{4}$ $1.5 \mathrm{~g}, \quad \mathrm{MgCl}_{2} \cdot 6 \mathrm{H}_{2} \mathrm{O} \quad 0.4 \mathrm{~g}, \quad \mathrm{NH}_{4} \mathrm{Cl} 0.9 \mathrm{~g}$, yeast extract $1.0 \mathrm{~g}$, cysteine- $\mathrm{HCl} 0.75 \mathrm{~g}, \mathrm{FeCl}_{3} \cdot 6 \mathrm{H}_{2} \mathrm{O} 2.5 \mathrm{mg}, \mathrm{NaCl} 0.9 \mathrm{~g}$, trypticase $2 \mathrm{~g}$, SL-10 (medium $320 \mathrm{DSMZ}$ ) trace elements $1 \mathrm{ml}$, and resazurin $0.5 \mathrm{mg}$. The $\mathrm{pH}$ was adjusted to 7.2 at room temperature. The culture medium was supplemented with $50 \mathrm{mmol} \mathrm{L}^{-1}$ 4-morpholine propanesulfonic acid (MOPS) to increase the buffering capacity of the medium. Medium was reduced with $0.75 \mathrm{~g} \mathrm{~L}^{-1}$ Cysteine- $\mathrm{HCl}$ monohydrated. Cellobiose $\left(2 \mathrm{~g} \mathrm{~L}^{-1}\right)$ was used as the carbon source for growing the culture. The medium was made anoxic by flushing with $100 \% \mathrm{~N}_{2}$. The experiments were carried out under sterile conditions. C. saccharolyticus was grown at $70^{\circ} \mathrm{C}$.

\subsubsection{Experiment set-up}

Hydrogen production assays were performed in $160 \mathrm{~mL}$ serum bottles containing $50 \mathrm{~mL}$ of phosphate-buffered medium $\left(20 \mathrm{mmol} \mathrm{L}^{-1}\right)$ and $50 \mathrm{mmol} \mathrm{L}^{-1}$ 4-morpholine propanesulfonic acid (MOPS) flushed with $\mathrm{N}_{2}$ (100\%). The medium was supplemented with trace elements solution SL-10 according to DSMZ 320 medium. Yeast extract and resazurin were added to a final concentration of $0.5 \mathrm{~g} \mathrm{~L}^{-1}$ and $0.5 \mathrm{mg} \mathrm{L}^{-1}$, respectively. Medium was reduced with $0.75 \mathrm{~g} \mathrm{~L}^{-1}$ Cysteine- $\mathrm{HCl}$ monohydrated. Three different Sargassum sp. concentrations (VS per L) (2.5, 4.9 and $7.4 \mathrm{~g} \mathrm{~L}^{-1}$ ) were tested. Before inoculation the bottles containing the different concentrations of Sargassum sp. were autoclaved at $121^{\circ} \mathrm{C}$ and $1 \mathrm{bar}$ for $15 \mathrm{~min}$. The autoclave functioned as thermal and pressure pretreatment for the Sargassum sp.

Two batch series with different initial inoculum concentrations were performed for each Sargassum sp. concentration. The inoculum CDW concentrations tested were 0.04 and $0.09 \mathrm{~g} \mathrm{~L}^{-1}$ of precultured C. saccharolyticus. Bottles were incubated at $70^{\circ} \mathrm{C}$ under shaking $(90 \mathrm{rpm})$. All the experiments were performed in quadruplicate and included controls without Sargassum sp. and without $C$. saccharolyticus. Production of hydrogen gas and soluble fermentation products were monitored.

\subsection{Methanogenic assays}

\subsubsection{Inoculum}

Anaerobic granular sludge from a brewery industry was used as inoculum in the methanogenic assays. The sludge contained a VS concentration of $0.08 \pm 0.01 \mathrm{~g} \mathrm{~g}^{-1}$. The specific methanogenic activity (SMA) that represents the methane production at standard temperature and pressure (STP) conditions per VS of granular sludge per day, in the presence of acetate $\left(30 \mathrm{mmol} \mathrm{L}^{-1}\right)$ was $156 \pm 5 \mathrm{~mL} \mathrm{~g}^{-1} \mathrm{~d}^{-1}$, and in the presence of $\mathrm{H}_{2} / \mathrm{CO}_{2}(80 / 20 \mathrm{v} / \mathrm{v}$, 1 bar) was $375 \pm 8 \mathrm{~mL} \mathrm{~g}^{-1} \mathrm{~d}^{-1}$. SMA was determined as described in Costa et al. (2012).

\subsubsection{Experiment set-up}

Methanogenic assays were performed according to the guidelines defined in Angelidaki et al. (2009), with a working volume of $120 \mathrm{~mL}$, at $37^{\circ} \mathrm{C}$. The hydrolysates obtained after $\mathrm{H}_{2}$ production were added to $600 \mathrm{~mL}$ serum bottles containing $20 \mathrm{~g}$ of inoculum and basal medium containing $\mathrm{NaHCO}_{3}\left(5 \mathrm{~g} \mathrm{~L}^{-1}\right)$. $\mathrm{pH}$ of the medium was corrected to 7.0-7.2 with $\mathrm{NaOH}$ or $\mathrm{HCl} 2 \mathrm{~mol} \mathrm{~L}^{-1}$. The vials were sealed and the headspace flushed with $\mathrm{N}_{2} / \mathrm{CO}_{2}(80: 20 \mathrm{v} / \mathrm{v})$. Before incubation, the medium was amended with $\mathrm{Na}_{2} \mathrm{~S} \cdot 9 \mathrm{H}_{2} \mathrm{O}$, to a final concentration of $1 \mathrm{mmol} \mathrm{L}^{-1}$.

Blank assays to discount for the residual substrate present in the inoculum were also performed.

The methane accumulated in the headspace of the closed bottles was measured by gas chromatography (GC), with a flame ionization detector (FID), using a gas tight syringe to sample $500 \mu \mathrm{L}$. Methane production was corrected for STP conditions ( $0{ }^{\circ} \mathrm{C}$ and $1 \mathrm{bar}$ ). Biochemical methane potential (BMP) was defined by the volume of methane produced per unit of COD of substrate added to the assay (Eq. (1)).

$\mathrm{BMP}=\mathrm{L} \mathrm{CH}_{4} / \mathrm{kgCOD}=\frac{\mathrm{kgCOD}-\mathrm{CH}_{4} \times 350\left(\mathrm{~L} \mathrm{CH}_{4} / \mathrm{kgCOD}\right)}{\mathrm{kg} \mathrm{COD}}$ 


\subsection{Analytical methods}

Determination of lignin, xylan and glucan was performed according to Sluiter et al. (2008). TKN, ammonium ( $\left.\mathrm{NH}_{4}^{+}\right)$, TS and VS were measured according to standard methods APHA (1989). Total and soluble COD were determined using standard kits (Hach Lange, Düsseldorf, Germany). Sample filtration was performed prior to soluble COD (CODs) determination. Lipids determination was carried out according to Bligh and Dyer (1959).

Hydrogen concentration in the gas phase was determined by GC using a column molsieve (MS-13 $\times 80 / 100$ mesh) and thermal conductivity detector Bruker Scion 456 Chromatograph, (Bruker, Massachusetts, USA) with argon $\left(30 \mathrm{~mL} \mathrm{~min}^{-1}\right)$ as the carrier gas. The injector, detector and column temperatures were 100,130 , and $35{ }^{\circ} \mathrm{C}$ respectively. Methane content in the biogas was analyzed by GC (Chrompack 9000) equipped with a FID detector and a $2 \mathrm{~m} \times 1 / 8^{\prime \prime}$ Chromosorb 101 (80-120 mesh) column, using nitrogen as carrier gas $\left(30 \mathrm{~mL} \mathrm{~min}^{-1}\right)$; column, injector, and detector temperatures were 35,110 , and $220^{\circ} \mathrm{C}$, respectively.

VFA, ethanol and lactic acid were determined by high performance liquid chromatography using an HPLC (Jasco, Japan) with a Chrompack column $\left(6.5 \times 30 \mathrm{~mm}^{2}\right)$; sulfuric acid $\left(0.005 \mathrm{~mol} \mathrm{~L}^{-1}\right)$ at a flow rate of $0.9 \mathrm{~mL} \mathrm{~min}^{-1}$ was used as mobile phase. Column temperature was set at $80^{\circ} \mathrm{C}$. Detection of VFA, lactic acid and ethanol was made sequentially using a UV detector at $210 \mathrm{~nm}$ and a RI detector.

\subsection{Data analysis}

The modified Gompertz equation was used to describe the progress of cumulative hydrogen production obtained from the batch experiments. Using the cumulative hydrogen production data, corrected to STP conditions $\left(0^{\circ} \mathrm{C}\right.$ and 1 bar), the maximum hydrogen production rates were estimated from the fit of the modified Gompertz equation (Eq. (2))

$H(t)=P \exp \left\{-\exp \left[\frac{R_{m} e}{P}(\lambda-t)+1\right]\right\}$

where $H(\mathrm{t})$ is cumulative hydrogen production $(\mathrm{mL}), P$ is the hydrogen production potential $(\mathrm{mL}), R m$ is the maximum hydrogen production rate $\left(\mathrm{mL} \mathrm{h}^{-1}\right), e=2.71828 \ldots, \lambda$ represents the lag-phase time $(h)$, and, $t$ is the time $(h)$.

\section{Results and discussion}

\subsection{Substrate characterization}

The results of Sargassum sp. characterization are shown in Table 1. In general, macroalgae are suitable for biogas production due to the high carbohydrates content that can go up to $60 \%$

Table 1

Characterization of Sargassum sp.

\begin{tabular}{lcl}
\hline Sargassum sp. & Before autoclave & After autoclave \\
\hline COD $_{\text {total }}\left(\mathrm{mg} \mathrm{g}^{-1}\right)$ & $600 \pm 62$ & $562 \pm 84$ \\
COD $_{\text {soluble }}\left(\mathrm{mg} \mathrm{g}^{-1}\right)$ & $15 \pm 0$ & $154 \pm 1$ \\
TS $\left(\mathrm{mg} \mathrm{g}^{-1}\right)$ & $896 \pm 2$ & \\
VS $\left(\mathrm{mg} \mathrm{g}^{-1}\right)$ & $490 \pm 8$ & \\
TKN $\left(\mathrm{mg} \mathrm{N} \mathrm{g}^{-1}\right)$ & $20 \pm 0$ & \\
Fat content (mg g & \\
Klason Lignin (\%VS) & $13 \pm 0$ & \\
Glucan (\%VS) & $3.3 \pm 0.9$ & \\
Xylan (\%VS) & $32.9 \pm 2.6$ & \\
\hline
\end{tabular}

Macroalgae dried at room temperature and milled into pieces with less than $0.5 \mathrm{~cm}$ depending on the species (Costa et al., 2012). Glucan and xylan content of Sargassum sp. represents $45 \%$ of the VS. These compounds are also suitable for fermentative hydrogen production. The low lipid content makes biodiesel production from Sargassum sp. biomass unfeasible. The low values of soluble COD and VS confirm the recalcitrant nature of this substrate. However, the lignin content is low ( $3.3 \pm 0.9 \%$ VS). An autoclaving pre-treatment $\left(121^{\circ} \mathrm{C}\right.$ and $1 \mathrm{bar}$ for $\left.15 \mathrm{~min}\right)$ was applied to Sargassum sp. to increase the soluble COD. After autoclaving the soluble COD increased $10 \times$, corresponding to more than $25 \%$ of the total COD.

\subsection{Biohydrogen dark fermentation of Sargassum $s p$}

Cumulative hydrogen production for each ratio substrate/inoculum tested is shown in Fig. 1. The highest hydrogen production was obtained with an initial culture CDW concentration of $0.09 \mathrm{~g} \mathrm{~L}^{-1}$ and concentration of Sargassum sp. (VS) of $7.4 \mathrm{~g} \mathrm{~L}^{-1}$. No hydrogen production was observed in the assay with inoculum concentration (CDW) of $0.04 \mathrm{~g} \mathrm{~L}^{-1}$ and $4.9 \mathrm{~g} \mathrm{~L}^{-1}$ of Sargassum sp. (VS).

Higher hydrogen production was achieved with the higher inoculum concentration tested, independently of the ratio substrate/inoculum. Lower hydrogen production $\left(0.30 \mathrm{mmolH}_{2}\right)$ was obtained with a substrate/inoculum ratio of $63: 1\left(2.5 \mathrm{~g} \mathrm{~L}^{-1}\right.$ of Sargassum sp. (VS) and $0.04 \mathrm{~g} \mathrm{~L}^{-1}$ of inoculum (CDW) comparing to $1.2 \mathrm{mmolH}_{2}$ achieved with a substrate/inoculum ratio of $82: 1$ ( $7.4 \mathrm{~g} \mathrm{~L}^{-1}$ of Sargassum sp. (VS) and $0.09 \mathrm{~g} \mathrm{~L}^{-1}$ of inoculum (CDW)). These results suggest that inoculum concentration is the main factor affecting hydrogen production from Sargassum sp. biomass, independently of the ratio used.

Cumulative hydrogen production data was used to estimate the parameters of the modified Gompertz equation (maximum hydrogen production rate and hydrogen production potential) shown in Table 2. The highest hydrogen production yield was achieved with Sargassum sp. concentration (VS) of $2.5 \mathrm{~g} \mathrm{~L}^{-1}$ and $0.09 \mathrm{~g} \mathrm{~L}^{-1}$ of inoculum (CDW) corresponding to hydrogen production of $91.3 \mathrm{~mL} \mathrm{~g}^{-1}$ and a maximum hydrogen production rate of $2.1 \mathrm{~mL} \mathrm{~g}^{-1} \mathrm{~h}^{-1}$ (Table 2). The lower hydrogen production yield $\left(60.8 \mathrm{~mL} \mathrm{~g}^{-1}\right)$ and rate $\left(0.54 \mathrm{~mL} \mathrm{~g}^{-1} \mathrm{~h}^{-1}\right)$ was observed with $0.04 \mathrm{~g} \mathrm{~L}^{-1}$ of inoculum (CDW) and $2.5 \mathrm{~g} \mathrm{~L}^{-1}$ of Sargassum sp. (VS).

For all the conditions tested it was observed that acetate was the sole soluble fermentation product (Fig. 2). The ratio $0.09 \mathrm{~g} \mathrm{~L}^{-1}$ of inoculum (CDW) and $7.4 \mathrm{~g} \mathrm{~L}^{-1}$ of Sargassum sp (VS) reached the higher acetate concentration $\left(13 \mathrm{mmol} \mathrm{L}^{-1}\right)$ corresponding also, to the ratio that achieved higher cumulative hydrogen production. Lactate was not produced in any of the conditions tested. C. saccharolyticus is capable to directly use NADH for hydrogen production, although, when the hydrogen partial pressure $\left(p\left(\mathrm{H}_{2}\right)\right)$ is high, the NADH is used by lactate dehydrogenase

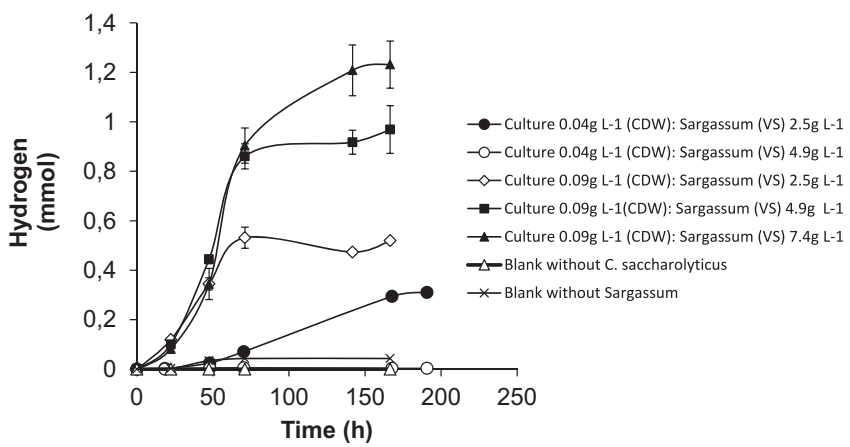

Fig. 1. Cumulative hydrogen production for each ratio inoculum/substrate tested. 
Table 2

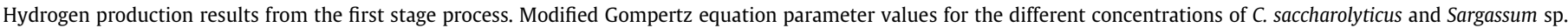
biomass.

\begin{tabular}{|c|c|c|c|c|c|}
\hline $\begin{array}{l}\text { Inoculum concentration } \\
(\mathrm{CDW})\left(\mathrm{g} \mathrm{L}^{-1}\right)\end{array}$ & $\begin{array}{l}\text { Concentration of Sargassum sp. } \\
\text { (VS) }\left(\mathrm{g} \mathrm{L}^{-1}\right)\end{array}$ & $\begin{array}{l}\text { Hydrogen production } \\
\left(\mathrm{mL} \mathrm{g}^{-1}\right)\end{array}$ & $\begin{array}{l}\text { Hydrogen production rate } \\
\left(\mathrm{mL} \mathrm{g}^{-1} \mathrm{~h}^{-1}\right)\end{array}$ & $R^{2}$ & $\begin{array}{l}\text { Maximum hydrogen partial } \\
\text { pressure }^{* * *}(\mathrm{kPa})\end{array}$ \\
\hline 0.04 & 2.5 & $60.8 \pm 1.4$ & $0.54 \pm 0.03$ & 0.999 & $12.5 \pm 0$ \\
\hline 0.04 & 4.9 & 0 & 0 & na & 0 \\
\hline 0.09 & 2.5 & $91.3 \pm 3.3$ & $2.1 \pm 0.4$ & 0.973 & $20.9 \pm 0.4$ \\
\hline 0.09 & 4.9 & $87.5 \pm 2.7$ & $1.83 \pm 0.3$ & 0.983 & $38.9 \pm 3.8$ \\
\hline 0.09 & 7.4 & $74.0 \pm 2.1$ & $1.56 \pm 0.2$ & 0.989 & $49.5 \pm 3.8$ \\
\hline
\end{tabular}

* Volume of hydrogen produced per grams of Sargassum sp. (VS).

** Volume of hydrogen produced per grams of Sargassum sp. (VS) per hour.

*** Above this hydrogen partial pressure $p\left(\mathrm{H}_{2}\right)$ no hydrogen was produced.

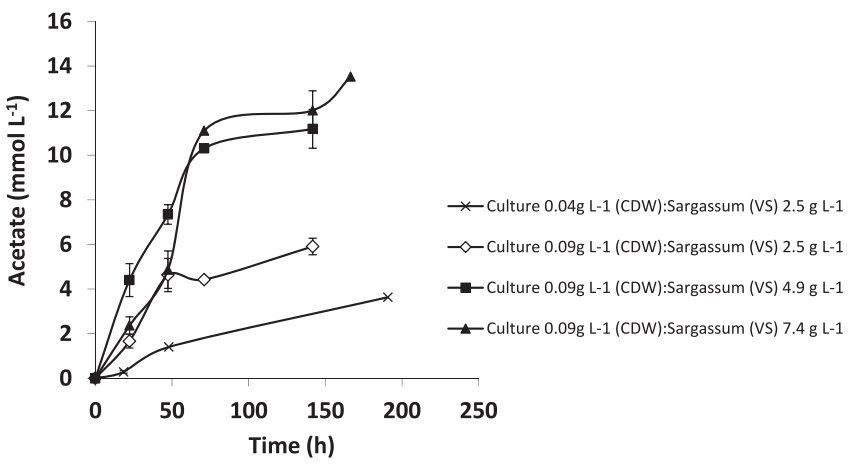

Fig. 2. Acetate formation during hydrogen dark fermentation process from each ratio inoculum/substrate tested.

to produce lactate instead of acetate and hydrogen (van de Werken et al., 2008). The maximum $p\left(\mathrm{H}_{2}\right)$ obtained in this study was $49.5 \times 10^{3} \mathrm{~Pa}$, for the ratio $0.09 \mathrm{~g} \mathrm{~L}^{-1}$ of inoculum (CDW) and $7.4 \mathrm{~g} \mathrm{~L}^{-1}$ of Sargassum sp. (VS) (Table 2). The $p\left(\mathrm{H}_{2}\right)$ achieved was not critical, since lactate formation was not observed as an alternative way for reoxidizing NADH.

\subsection{Methane production from Sargassum sp. dark fermentation end products}

After $\mathrm{H}_{2}$ production, the biochemical methane potential of the resulting fermentation end products was assessed in batch tests. The initial total COD varied between 7.1 and $9.6 \mathrm{~g} \mathrm{~L}^{-1}$ (Table 3). The assays lasted 42 days, although $80 \%$ of the maximum methane production was achieved around day 20 (Fig. 3). The results from the anaerobic biodegradability assays are shown in Table 3.

The highest methane production per mass (VS) of substrate, $541 \pm 10 \mathrm{~L} \mathrm{~kg}^{-1}$, was attained in the assay performed with the fermentation products of the first stage dark fermentation carried out with concentration of Sargassum sp. (VS) of $2.5 \mathrm{~g} \mathrm{~L}^{-1}$. Higher Sargassum sp. concentrations in the dark fermentation step, led to lower methane yields (Table 3 ), though $\mathrm{pH}$ and ammonium

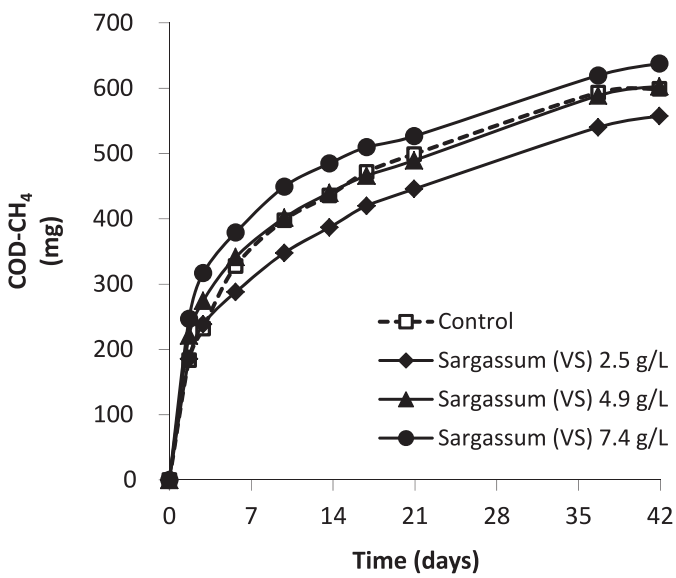

Fig. 3. Specific methane production from the dark fermentation products of each ratio inoculum/substrate. Control assay was performed with substrate (Sargassum sp.) and without Caldicellulosiruptor saccharolyticus.

concentration at the end of the anaerobic biodegradability assays did not reach inhibitory values. The higher solubilization yield as confirmed by the higher concentration of soluble COD, may suggest the accumulation of potentially inhibitory soluble metabolites.

Substrate solubilisation during the methanogenic step, was higher in the presence of $C$. saccharolyticus suggesting a positive effect of the acidogenic strain in the process of solubilisation even during the methanogenic step at mesophilic conditions (Table 3).

However, the overall efficiency of the methanogenic process was not directly dependent on the presence of $C$. saccharolyticus. For example, in the two assays with concentration of Sargassum sp. (VS) of $4.9 \mathrm{~g} \mathrm{~L}^{-1}$ the BMP were $336 \pm 14$ and $345 \pm 10 \mathrm{~L} \mathrm{~kg}^{-1}$, respectively with and without $C$. saccharolyticus.

\subsection{Biohythane production}

The present study suggests that biohythane production from Sargassum sp. has a great potential. Hydrogen and methane yields

Table 3

Experimental results obtained from the anaerobic biodegradability assays (second stage process).

\begin{tabular}{|c|c|c|c|c|c|c|}
\hline \multicolumn{2}{|l|}{ Dark fermentation conditions } & \multirow{2}{*}{$\begin{array}{l}\text { Dark fermentation end } \\
\text { products } \\
\text { CODt }\left(\mathrm{g} \mathrm{L}^{-1}\right)\end{array}$} & \multirow{2}{*}{$\begin{array}{l}\mathrm{BMP}^{*} \\
\left(\mathrm{~L} \mathrm{~kg}^{-1}\right)\end{array}$} & \multirow[t]{2}{*}{$\mathrm{pH}$} & \multirow{2}{*}{$\begin{array}{l}\text { CODs } \\
\left(\mathrm{g} \mathrm{L}^{-1}\right)\end{array}$} & \multirow{2}{*}{$\begin{array}{l}\mathrm{NH}_{4}^{+} \\
\left(\mathrm{mg} \mathrm{L}^{-1}\right)\end{array}$} \\
\hline $\begin{array}{l}\text { Inoculum concentration (CDW) } \\
\left(\mathrm{g} \mathrm{L}^{-1}\right)\end{array}$ & $\begin{array}{l}\text { Concentration of Sargassum sp (VS) } \\
\left(\mathrm{g} \mathrm{L}^{-1}\right)\end{array}$ & & & & & \\
\hline 0.09 & 2.5 & $7.08 \pm 0$ & $541 \pm 10$ & 7.3 & $4.11 \pm 0.16$ & $603 \pm 1$ \\
\hline 0.09 & 4.9 & $8.06 \pm 0.06$ & $345 \pm 10$ & 7.1 & $4.30 \pm 0.02$ & $599 \pm 13$ \\
\hline 0.09 & 7.4 & $9.58 \pm 0.06$ & $281 \pm 7$ & 7.1 & $4.46 \pm 0.05$ & $610 \pm 14$ \\
\hline _- & 4.9 & $7.53 \pm 0.64$ & $339 \pm 14$ & 7.3 & $3.57 \pm 0.24$ & $597 \pm 15$ \\
\hline
\end{tabular}

* BMP - Methane produced (L) per kg of Sargassum sp. (VS) used in the dark fermentation process. 
Table 4

Performance of two-stage hydrogen and methane fermentation from different feedstocks (adapted from Liu et al. (2013)).

\begin{tabular}{|c|c|c|c|c|c|c|c|c|}
\hline Substrate & $\mathrm{H}_{2}$ inoculum & $\begin{array}{l}\mathrm{H}_{2} \\
\text { operation }\end{array}$ & $\mathrm{H}_{2}$ yield & $\mathrm{CH}_{4}$ inoculum & $\mathrm{CH}_{4}$ operation & $\mathrm{CH}_{4}$ yield $^{*}$ & $\begin{array}{l}\% \text { of } \mathrm{H}_{2} \text { in } \\
\text { hythane } \\
\text { (v/v) }\end{array}$ & Reference \\
\hline $\begin{array}{l}\text { Wheat straw } \\
\text { hydrolysate }\end{array}$ & Granular sludge & Continuous & $89 \mathrm{~L} \mathrm{~kg}^{-1} \mathrm{VS}$ & $\begin{array}{l}\text { Granular sludge and } \\
\text { digested manure }\end{array}$ & Continuous & $307 \mathrm{~L} \mathrm{~kg}^{-1} \mathrm{VS}$ & 22 & $\begin{array}{l}\text { Kongjan et al. } \\
\text { (2011) }\end{array}$ \\
\hline Grass silage & $\begin{array}{l}\text { Cow manure } \\
\text { sludge }\end{array}$ & Batch & $6.46 \mathrm{~L} \mathrm{~kg}^{-1} \mathrm{VS}$ & Cow manure sludge & Batch & $467 \mathrm{~L} \mathrm{~kg}^{-1} \mathrm{VS}$ & 1 & $\begin{array}{l}\text { Pakarinen } \\
\text { et al. (2009) }\end{array}$ \\
\hline Cornstalk & $\begin{array}{l}\text { Granular sludge } \\
\text { and pure culture }\end{array}$ & Batch & $64 \mathrm{~L} \mathrm{~kg}^{-1} \mathrm{TS}$ & Granular sludge & Batch & $115 \mathrm{~L} \mathrm{~kg}^{-1} \mathrm{TS}$ & 36 & Lu et al. (2009) \\
\hline $\begin{array}{l}\text { Lipid extracted } \\
\text { microalgal } \\
\text { biomass }\end{array}$ & Anaerobic sludge & Batch & $46 \mathrm{~L} \mathrm{~kg}^{-1} \mathrm{VS}$ & Anaerobic sludge & Batch & $394 \mathrm{~L} \mathrm{~kg}^{-1} \mathrm{VS}$ & 10 & $\begin{array}{l}\text { Yang et al. } \\
\text { (2011) }\end{array}$ \\
\hline $\begin{array}{l}\text { Sweet sorghum } \\
\text { biomass }\end{array}$ & $\begin{array}{l}\text { Indigenous } \\
\text { microflora }\end{array}$ & Continuous & $10.4 \mathrm{~L} \mathrm{~kg}^{-1} \mathrm{VS}$ & Anaerobic sludge & Continuous & $107 \mathrm{~L} \mathrm{~kg}^{-1} \mathrm{VS}$ & 9 & $\begin{array}{l}\text { Antonopoulou } \\
\text { et al. (2008) }\end{array}$ \\
\hline Cassava stillage & Anaerobic sludge & Continuous & $56.6 \mathrm{~L} \mathrm{~kg}^{-1} \mathrm{VS}$ & Continuous & $\begin{array}{l}\text { Thermophilic } \\
\text { digested cassava } \\
\text { stillage }\end{array}$ & $249 \mathrm{~L} \mathrm{~kg}^{-1} \mathrm{VS}$ & 19 & $\begin{array}{l}\text { Luo et al. } \\
\text { (2010) }\end{array}$ \\
\hline Sargassum sp. & $\begin{array}{l}\text { Caldicellulosiruptor } \\
\text { saccharolyticus }\end{array}$ & Batch & $91 \mathrm{~L} \mathrm{~kg}^{-1} \mathrm{VS}$ & Granular sludge & Batch & $541 \mathrm{~L} \mathrm{~kg}^{-1} \mathrm{VS}$ & 14 & This study \\
\hline Sargassum sp. & $\begin{array}{l}\text { Caldicellulosiruptor } \\
\text { saccharolyticus }\end{array}$ & Batch & $88 \mathrm{~L} \mathrm{~kg}^{-1} \mathrm{VS}$ & Granular sludge & Batch & $345 \mathrm{~L} \mathrm{~kg}^{-1} \mathrm{VS}$ & 20 & This study \\
\hline
\end{tabular}

* $\mathrm{kg}$ of VS used in the dark fermentation process.

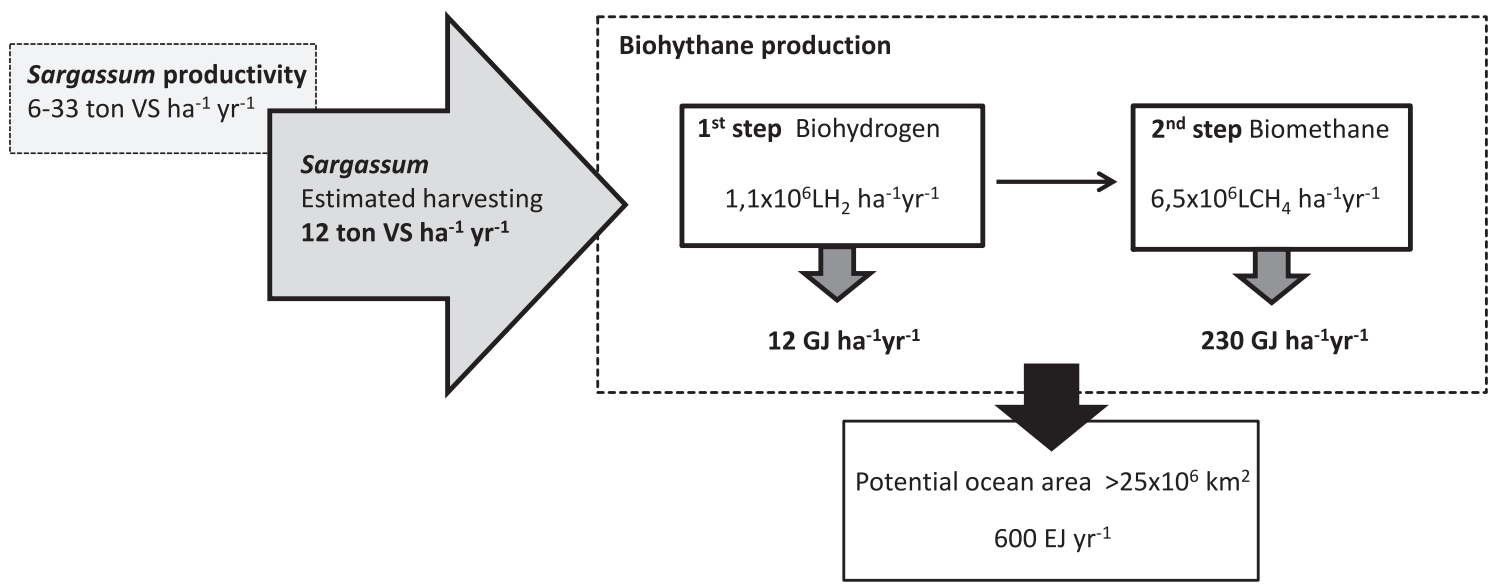

Fig. 4. Potential energy generation from Sargassum sp. according to the maximum hydrogen and methane production achieved in the present study.

obtained were higher than others reported in the literature for complex substrates (Table 4).

The maximum $\mathrm{H}_{2}$ and $\mathrm{CH}_{4}$ production was achieved with Sargassum sp. concentration (VS) of $2.5 \mathrm{~g} \mathrm{~L}^{-1}$ (Tables 2 and 3). This would represent the generation of biohythane with $14 \% \mathrm{H}_{2}$ (Table 4), which is within the optimal range (10-25\%). However, it is possible to increase the $\mathrm{H}_{2}$ percentage in the biohythane up to $20 \%$ by using a higher concentration of Sargassum sp. (VS) $\left(4.9 \mathrm{~g} \mathrm{~L}^{-1}\right.$ ) (Table 4).

\subsection{Potential energy generation}

Annual productivity of Sargassum sp. varies between 6 and 33 ton ha ${ }^{-1} \mathrm{yr}^{-1}$ (N'Yeurt et al., 2012) in terms of VS. Considering a feasible sustainable annual harvest amount of 12 ton ha $\mathrm{hr}^{-1}$, the energy generation predictable according to the maximum hydrogen and methane production potential achieved in the present study (Fig. 4), is $12 \mathrm{GJ} \mathrm{ha}^{-1} \mathrm{yr}^{-1}$ from the first step and $230 \mathrm{GJ} \mathrm{ha}^{-1} \mathrm{yr}^{-1}$ from the second step. According to Reith et al. (2012), the ocean potential area for macroalgae production could exceed $25 \times 10^{6} \mathrm{~km}^{2}$. Therefore, the value of energy herein demonstrated of $242 \mathrm{GJ} \mathrm{ha}^{-1} \mathrm{yr}^{-1}$ could result in a maximum energy supply of $600 \mathrm{EJ} \mathrm{yr}^{-1}$, 6-fold higher the value estimated by Chynoweth et al. (2001), covering theoretically the annual world energy consumption. These figures are theoretical and do not include the energy requirements for the whole process.

\section{Conclusion}

The highest hydrogen and methane production yields were achieved with Sargassum sp. concentration (VS) of $2.5 \mathrm{~g} \mathrm{~L}^{-1}$ and $0.09 \mathrm{~g} \mathrm{~L}^{-1}$ of inoculum concentration (CDW), namely $91.3 \pm 3.3 \mathrm{~L}$ $\mathrm{H}_{2}$ and $541 \pm 10 \mathrm{~L} \mathrm{CH}_{4}$ per $\mathrm{kg}$ (VS) of Sargassum sp., resulting in biohythane with $14 \%$ hydrogen. Potential energy production from Sargassum sp. in two stage process was estimated in $242 \mathrm{GJ} \mathrm{ha}^{-1} \mathrm{yr}^{-1}$. Considering the ocean potential area for macroalgae production of $25 \times 10^{6} \mathrm{~km}^{2}$, the value of energy herein demonstrated could result in a potential energy supply of $600 \mathrm{EJ} \mathrm{yr}^{-1}$.

\section{Acknowledgements}

The authors acknowledge the financial support of the Portuguese Science Foundation (FCT) and European Social Fund (ESF, POPH-QREN) through the grants given to A.A. Abreu 
(SFRH/BPD/82000/2011) and J.C. Costa (SFRH/BDP/48962/2008), and through the project FCOMP-01-0124-FEDER-027914 (PTDC/AAG-TEC/3048/2012), financed by FEDER through COMPETE - Programa Operacional Factores de Competitividade; and FCT Strategic Project PEst-OE/EQB/LA0023/2013, the FCT Project RECI/BBB-EBI/0179/2012 and the Project "BioEnv Biotechnology and Bioengineering for a sustainable world", REF. NORTE-07-0124-FEDER-000048, co-funded by the Programa Operacional Regional do Norte (ON.2 - O Novo Norte), QREN, FEDER.

\section{References}

Abreu, A.A., Alves, J.I., Pereira, M.A., Karakashev, D., Alves, M.M., Angelidaki, I., 2010. Engineered heat treated methanogenic granules: a promising biotechnological approach for extreme thermophilic biohydrogen production. Bioresour. Technol. 101 (24), 9577-9586.

Abreu, A.A., Karakashev, D., Angelidaki, I., Sousa, D.Z., Alves, M.M., 2012. Biohydrogen production from arabinose and glucose using extreme thermophilic anaerobic mixed cultures. Biotechnol. Biofuels, 5-6.

Angelidaki, I., Alves, M., Bolzonella, D., Borzacconi, L., Campos, J.L., Guwy, A.J., Kalyuzhnyi, S., Jenicek, P., van Lier, J.B., 2009. Defining the biomethane potential (BMP) of solid organic wastes and energy crops: a proposed protocol for batch assays. Water Sci. Technol. 59 (5), 927-934.

Antonopoulou, G., Gavala, H.N., Skiadas, I.V., Angelopoulos, K., Lyberatos, G., 2008 Blofuels generation from sweet sorghum: fermentative hydrogen production and anaerobic digestion of the remaining biomass. Bioresour. Technol. 99 (1), $110-119$.

APHA, Awwa WPC, 1989. Standard methods for the examination of water and wastewater, seventeenth ed. American Public Health Association, Washington, DC, USA.

Banks, C.J., Zotova, E.A., Heaven, S., 2010. Biphasic production of hydrogen and methane from waste lactose in cyclic-batch reactors. J. Clean. Prod. 18, 95-104.

Bauer, C.G., Forest, T.W., 2001. Effect of hydrogen addition on the performance of methane-fueled vehicles. Part I: effect on SI engine performance. Int. J. Hydrogen Energy 26 (1), 55-70.

Bligh, E.G., Dyer, W.J., 1959. A rapid method for total lipid extraction and purification. Can. J. Biochem. Physiol. 37, 911-917.

Briand, X., Morand, P., 1997. Anaerobic digestion of Ulva sp. 1. Relationship between Ulva composition and methanisation. J. Appl. Phycol. 9, 511-524.

Chynoweth, D.P., Owens, J.M., Legrand, R., 2001. Renewable methane from anaerobic digestion of biomass. Renew. Energy 22, 1-8.

Costa, J.C., Goncalves, P.R., Nobrel, A., Alves, M.M., 2012. Biomethanation potential of macroalgae Ulva spp. and Gracilaria spp. and in co-digestion with waste activated sludge. Bioresour. Technol. 114, 320-326.

Das, L.M., Gulati, R., Gupta, P.K., 2000. A comparative evaluation of the performance characteristics of a spark ignition engine using hydrogen and compressed natural gas as alternative fuels. Int. J. Hydrogen Energy 25 (8), 783-793.
Kongjan, P., Thong, S., Angelidaki, I., 2011. Performance and microbial community analysis of two-stage process with extreme thermophilic hydrogen and thermophilic methane production from hydrolysate in UASB reactors. Bioresour. Technol. 102 (5), 4028-4035.

Liu, Z.D., Zhang, C., Lu, Y., Wu, X., Wang, L., Wang, L.J., Han, B., Xing, X.H., 2013. States and challenges for high-value biohythane production from waste biomass by dark fermentation technology. Bioresour. Technol. 135, 292-303.

Ljunggren, M., Zacchi, G., 2010. Techno-economic analysis of a two-step biological process producing hydrogen and methane. Bioresour. Technol. 101 (20), 7780 7788.

Lu, Y., Lai, Q.H., Zhang, C., Zhao, H.X., Ma, K., Zhao, X.B., Chen, H.Z., Liu, D.H., Xing, X.H., 2009. Characteristics of hydrogen and methane production from cornstalks by an augmented two- or three-stage anaerobic fermentation process. Bioresour. Technol. 100 (12), 2889-2895.

Luo, G., Xie, L., Zou, Z.H., Wang, W., Zhou, Q., Shim, H.J., 2010. Anaerobic treatment of cassava stillage for hydrogen and methane production in continuously stirred tank reactor (CSTR) under high organic loading rate (OLR). Int. J. Hydrogen Energy 35 (21), 11733-11737.

Nkemka, V.N., Murto, M., 2010. Evaluation of biogas production from seaweed in batch tests and in UASB reactors combined with the removal of heavy metals. J. Environ. Manage. 91, 1573-1579.

N'Yeurt, A.R., Chynoweth, D.P., Capron, M.E., Stewart, J.R., Hasan, M.A., 2012 Negative carbon via Ocean Afforestation. Process Saf. Environ. 90, 467-474.

Pakarinen, O.M., Tahti, H.P., Rintala, J.A., 2009. One-stage $\mathrm{H}_{2}$ and $\mathrm{CH}_{4}$ and two-stage $\mathrm{H}_{2}+\mathrm{CH}_{4}$ production from grass silage and from solid and liquid fractions of $\mathrm{NaOH}$ pre-treated grass silage. Biomass Bioenerg. 33 (10), 1419-1427.

Reith, J.H., van Hal, J.W., Lenstra, W.J., 2012. Large-scale carbon recycling via cultivation and biorefinery of seaweeds for production of biobased chemicals and fuels. ECN-L-12-054.

Sluiter, A., Hames, B., Ruiz, R., Scarlata, C., Sluiter, J., Templeton, D., Crocker, D., 2008 Determination of structural carbohydrates and lignin in biomass laboratory analytical procedure (LAP), Technical Report NREL/TP-510-42618.

van de Werken, H.J.G., Verhaart, M.R.A., VanFossen, A.L., Willquist, K., Lewis, D.L., Nichols, J.D., Goorissen, H.P., Mongodin, E.F., Nelson, K.E., van Niel, E.W.J., Stams, A.J.M., Ward, D.E., de Vos, W.M., van der Oost, J., Kelly, R.M., Kengen, S.W.M. 2008. Hydrogenomics of the Extremely thermophilic bacterium Caldicellulosiruptor saccharolyticus. Appl. Environ. Microbiol. 74 (21), 6720 6729.

van Niel, E.W.J., Budde, M.A.W., de Haas, G.G., van der Wal, F.J., Claasen, P.A.M., Stams, A.J.M., 2002. Distinctive properties of high hydrogen producing extreme thermophiles, Caldicellulosiruptor saccharolyticus and Thermotoga elfii. Int. J. Hydrogen Energy 27 (11-12), 1391-1398.

Verhaart, M.R.A., Bielen, A.A.M., van der Oost, J., Stams, A.J.M., Kengen, S.W.M., 2010 Hydrogen production by hyperthermophilic and extremely thermophilic bacteria and archaea: mechanisms for reductant disposal. Environ. Technol. 31 (8-9), 993-1003.

Willquist, K., Zeidan, A.A., van Niel, E.W., 2010. Physiological characteristics of the extreme thermophile Caldicellulosiruptor saccharolyticus: an efficient hydrogen cell factory. Microb. Cell Fact. 9.

Yang, Z.M., Guo, R.B., Xu, X.H., Fan, X.L., Luo, S.J., 2011. Hydrogen and methane production from lipid-extracted microalgal biomass residues. Int. J. Hydrogen Energy 36 (5), 3465-3470. 